\title{
Evaluation on Dispositional Mental Functions of Cognitive, Affective, and Conative in Mathematical Power Problems-Solving Activity
}

\author{
Imam Kusmaryono \\ Sultan Agung Islamic University, Semarang, Indonesia \\ Hardi Suyitno \\ Dwijanto \\ Nur Karomah Dwidayati \\ Semarang State University, Indonesia
}

This research used mixed method with sequential explanatory strategy. This research aimed to (1) determine average achievement score in mathematical power ability test, (2) determine the mean score of mathematical disposition obtained from student's mathematics learning, (3) find out the influential existence of student mathematical disposition on mathematical power ability, (4) evaluate the achievement of indicators of dispositional mental function, and (5) describe the relation of mathematics dispositional mental function on students mathematical power in problem solving. Data source was 30 (thirty) eighth graders from a junior high school in Semarang, Indonesia. Methods of data collection were test, questionnaire, observation, and interview. Results of the quantitative study showed that mathematical disposition $(X)$ had a significant (52.8\%) influence on the ability of mathematical power $(Y)$ by linear regression equation model $Y=34.022+0.442 X$. Results of the qualitative study indicated there was an internal consistency among three mental functions of mathematical disposition. Reciprocal relation also occurred between mathematical power and mathematical disposition.

Keywords: mathematical disposition, mathematical power, problem solving

The issue of mathematics education reform in the global era has changed the paradigm of mathematics learning. The purpose of mathematics learning has focused on meaningful learning for students and can provide adequate competence for further study or to enter the workforce. The attempt to reform the learning of mathematics is to describe students to participate actively in learning. That is the nature of the "transmission" becoming "participation". When students learn math, their role of students is to build knowledge. The teacher gives problems, asks questions, hears students' answers, probes questions and then waits for answers from students in building their own knowledge. So, students have reasoning skills, critical and creative thinking skills that are actualized in high mathematical power abilities. 
The curriculum of Indonesia education implicitly demands students in elementary school through senior high school to have a firm mathematical power. In the content standard curriculum (2013) for elementary and high school, it is mentioned that mathematics learning competence is to have confidence on mathematical power and mathematics function formed by learning experience (Badan Standar Nasional Pendidikan [BSNP], 2013).

Why is mathematical power important? Mathematical power is part of higher-order thinking skills and has become the focus of the development of mathematics education in the $21^{\text {st }}$ century (National Council of Teachers of Mathematics [NCTM], 1989a). The ability to engage in importance of higherorder thinking is needed by our young people for the challenges of the $21^{\text {th }}$ century (Griffin, McGaw \& Care, 2012 in Kusmaryono \& Suyitno, 2015). Mathematical power can be developed from the level of very young children and the mathematics power has become an important goal of present mathematics learning (Diezmann, Watters, \& English, 2001; NCTM, 1989a; Phillips \& Anderson, 1993).

Mathematics learning is a much greater effort than simply helping students to acquire problem-solving skills and strategies. Teachers should also seek to develop positive motivation and disposition for learning mathematics aspects that will have long-term effects in everything starting from students' belief on mathematics (NCTM, 1989); including whether math will be their career choice or not. Therefore, every mathematics learning should consider the purpose of developing affective mental function, that is, the level of student motivation and disposition.

Students' mathematical disposition grows throughout mathematics learning. Therefore, the learning in a classroom must be specifically designed in an innovative and creative manner so that productive mathematical disposition can be developed. Conversely, while learning in the classroom still applies conventional methods which are neither innovative nor creative, a negative mathematical disposition will more possibly emerge. Students with a mathematical disposition negative generally show low self-confidence and are less motivated to learn mathematics (An, Zhang, Flores, Chapman, Tillman, \& Serna, 2015).

\section{Theoretical Background}

\section{Mathematical Power and Disposition}

Mathematical power is a collection of abstract thinking ability (high level thinking) which is very important to be developed as a stock for students in problem-solving activities and career achievements in the future. Although result of a previous research (Yeşildere \& Türnüklü, 2008) stated that students' mathematical ability on communication skills, connection and reasoning aspects is still very low. Basically all students can be seen to have abilities in mathematical power, but the level or degree of mathematical power possessed 
by every students is different and construction are also different ways (Kusmaryono \& Suyitno, 2015). Therefore, current education reformation is to develop students' mathematical power starting from youth level has become an important objective of today's mathematics learning (NCTM, 1989). In line with NCTM vision (1989a) on mathematical power for all has become part of mathematics learning objectives in Indonesia.

After reviewing some related literatures, (NCTM, 2000; Pilten, 2010; Şahin \& Baki, 2010; Scusa, 2008), mathematical power in this research topic, is defined as a student ability to use mathematics knowledge in solving nonroutine problems, by observing and assuming, logical reasoning (reasoning); communicating mathematics ideas (communication); and connecting the ideas in mathematics or along with other disciplines (connection) in order to improve self-confidence and mathematical disposition.

NCTM (1989) states that mathematical disposition is a student's appreciation on mathematic. The appreciation is such a tendency to positively think and act toward mathematics. Students' positive actions will do whenever they come up with confidence to solve mathematical problems, a high curiosity, diligence, and always reflecting on what has been done. Disposition is not a behavior but rather a determinant of behavior and represents the ways by which a person observes something (Mueller \& Hindin, 2011).

According to NCTM (1989), mathematical disposition contains seven components. Those are as follows, (1) confidence in using mathematics, (2) flexible in doing mathematical work, (3) persistent in solving mathematics tasks, (4) curious in math, (5) reflecting on the way of thinking, (6) appreciating mathematical applications, and (7) appreciating the role of mathematics.

Considering the mathematical disposition components mentioned by $\operatorname{NCTM}(2014)$, it turns out that the components are simply a part of mathematics learning objectives at schools contained in Content Standards of Indonesia Curriculum 2013 as follows, (1) showing a logical, critical, analytical, accurate and precise, responsible and determined attitude, (2) having a curiosity, confidence, and interest on mathematics, and (3) having a trust of mathematics power and usage formed through learning experiences (BSNP, 2013).

Christopher and Woods (2009), and NCTM (2014) describe a productive mathematical disposition is defined as a person's belief and attitude about mathematics which support the tendency to consider mathematics as a logical, useful, and valuable thing. Based on the results of previous research conducted by Snow, Corno, and Jackson III as delivered by Beyers (2011), there are three modes of mental function that is cognitive, affective, and conative that can be used to distinguish three categories of which all mental processes are classified, since those three modes function altogether.

In mathematics learning, students' mathematical disposition develops as they learn other competence aspects. For example, when students develop strategic competence to solve non-routine problems, their attitude and belief as learners become more positive. The more concepts understood by students, the 
more students are convinced that the mathematics can be mastered. Conversely, when students are rarely given a challenge of non-routine mathematical problems to solve, students tend to memorize rather than apply proper ways in learning mathematics, and they begin to lose confidence as learners. The statement is in line with James Beyers' research that concludes mental dispositional functions of cognitive, affective, and conative contribute to the mathematical disposition of students (Beyers, 2011).

\section{Dispositional Mental Functions}

Cognitive dispositional mental function is defined as a process by which a person (a student) becomes aware or acquires knowledge about an object (Beyers, 2011). It includes the tendency or desire to be involved (or not) in a cognitive mental process, such as observing, recognizing, judging, reasoning or providing reasons etc., in mathematics. The use of sensing is usually included under cognition.

Affective dispositional mental function is said to be a tendency of a feeling and response to an object or idea. Common reactions to affective mental function domains include attitudes, beliefs, likes or dislikes, emotions or important qualities of emotions, moods, and temperaments and responses to mathematics.

Conative dispositional mental function is said that way if a person has a tendency or desire to do his efforts, to practice persistently, or to diligently deal with mathematics activities. The situation in which students deal with difficult mathematical tasks and observes different levels of student involvement in challenging mathematical tasks.

In this study, cognitive dispositional mental function includes two subcategories namely connection and argumentation. Affective dispositional mental function includes six subcategories of nature of mathematics, usefulness, worthwhileness, sensibleness, self-concept mathematics, attitude, math anxiety. Conative dispositional mental function includes only one subcategory of effort/persistence (Beyers, 2011).Description of the subcategories of dispositional mental functions is shown in Table 1 which has been developed by James Beyers (2011) below.

\section{Purpose and Questions Addressed in this Study}

Purposes of this research were (1) to determine the effect of mathematical disposition on mathematical power, (2) to evaluate the attainment of mathematical dispositional mental function indicators, and (3) to describe the relation of mathematical dispositional mental function and students' mathematical power in problem solving. Result of the study provides benefits for teachers as an effort to increase teachers' active participation in encouraging the use of three modes of dispositional mental function by students, so that the 
productive mathematical disposition develops, problem-solving ability improves and students' mathematical power grow.

Table 1

Descriptions of Subcategories of Dispositional Mental Functions

\begin{tabular}{|c|c|c|}
\hline $\begin{array}{l}\text { Modes of Mental } \\
\text { Functioning }\end{array}$ & $\begin{array}{l}\text { Subcategory of } \\
\text { dispositional } \\
\text { function }\end{array}$ & Description of subcategory \\
\hline \multirow[t]{2}{*}{$\begin{array}{l}\text { Dispositional cognitive } \\
\text { function }\end{array}$} & Connections & $\begin{array}{l}\text { A tendency to try and connect } \\
\text { ideas with or across mathematical } \\
\text { topics. }\end{array}$ \\
\hline & Argumentation & $\begin{array}{l}\text { A tendency to evaluate the } \\
\text { mathematical correctness of } \\
\text { statements, make mathematical } \\
\text { arguments, justify mathematical } \\
\text { statements, etc. }\end{array}$ \\
\hline \multirow[t]{7}{*}{$\begin{array}{l}\text { Dispositional affective } \\
\text { function }\end{array}$} & $\begin{array}{l}\text { Nature of } \\
\text { Mathematics }\end{array}$ & $\begin{array}{l}\text { A belief about mathematics being } \\
\text { more procedural or conceptual in } \\
\text { nature }\end{array}$ \\
\hline & Usefulness & $\begin{array}{l}\text { A belief about the usefulness of } \\
\text { mathematics for meeting current } \\
\text { or future needs in or out of } \\
\text { school, for your career, etc. }\end{array}$ \\
\hline & Worthwhileness & $\begin{array}{l}\text { A value judgment that the work } \\
\text { put forth in learning mathematics } \\
\text { has been worth it to the student }\end{array}$ \\
\hline & Sensibleness & $\begin{array}{l}\text { A belief that mathematics is } \\
\text { composed of ideas that can be } \\
\text { made sense of. }\end{array}$ \\
\hline & $\begin{array}{l}\text { Mathematics Self- } \\
\text { Concept }\end{array}$ & $\begin{array}{l}\text { What the student believes about } \\
\text { him or herself as a leaner of } \\
\text { mathematics }\end{array}$ \\
\hline & Attitude & $\begin{array}{l}\text { The respondent's emotional } \\
\text { reactions to mathematical activity } \\
\text { in or out school, e.g., like, hate, } \\
\text { etc. }\end{array}$ \\
\hline & Math Anxiety & $\begin{array}{l}\text { Whether or not the student } \\
\text { experiences anxiety in relation to } \\
\text { mathematics }\end{array}$ \\
\hline $\begin{array}{l}\text { Dispositional conative } \\
\text { function }\end{array}$ & Effort/Persistence & $\begin{array}{l}\text { A tendency to persist or exert } \\
\text { effort if necessary. }\end{array}$ \\
\hline
\end{tabular}

Questions that arose in this research were (1) What is the average score obtained from students in mathematical power ability test? (2) What is the mean score of productive and nonproductive mathematical disposition obtained by students in mathematics learning? (3) Is there any influence from student mathematical disposition toward mathematical power ability? and (4) How is 
the description on relation of mathematics dispositional mental function with student mathematical power in problem solving?

\section{Methodology}

\section{Research Design}

This research used mixed method with sequential explanatory strategy. The first stage was collecting and analyzing quantitative data, then collecting and analyzing qualitative data based on the quantitative data (Creswell, 2014). The data source was 30 of 8th graders in junior high school in Semarang, Indonesia. In this study, mathematics learning was managed by applying group investigation learning model which, was conducted for five weeks on polyhedral chapter.

\section{Participants}

Participants in this research were Mrs. Ani Wantini and Mrs. Nurhayati as a model teacher conducting group investigation-based learning. Mrs. Ani Wantini is a mathematics teacher with 12 years teaching experience in junior high school, and Mrs. Nurhayati has 3 years teaching experience in mathematics. There were thirty students participating in this research. The students were about 12 to 14 years old. They were 8 th graders of the junior high school.

\section{Procedure}

This research was conducted in June 2017. It was conducted for 5 weeks by applying mathematics learning with group investigation learning approach. On the first to fifth week of learning, an observation on students' learning activity was managed. The learning activity (student and teacher activity) was observed, noted, and recorded in form of audio visual. On the first week, 30 students handed a questionnaire to determine level of mathematical disposition on mathematics. The questionnaire of mathematical disposition contained 20 statements (Appendix B). In the final meeting (fifth week), a test was conducted to measure 8th graders' mathematical power ability (Appendix A).

Quality of question items was reviewed in terms of: validity and reliability. Before being tested, the test instrument was validated its construction by an expert team as reviewers. Data was collected by using methods of test, observation, questionnaires, and interview. Analysis on the question items was conducted in quantitative way based on the data of items that had been tested on 20 subjects.

After that, 3 students (chosen subjects) were interviewed to collect indepth information about dispositional mental function. The interview was conducted by Think Out Loud (Think Aloud) technique, that was conducted based on certain considerations in choosing student representatives (subjects) to be interviewed (Herna, Nusantara, Subanji, \& Mulyati, 2016; Subanji \& 
Nusantara, 2016) When the interview was done, yet the information needed was not acquired, a similar treatment would be applied to other students in each group, until the qualified subject was acquired.

\section{Data Collection}

Data collection method was conducted by test, questionnaire, observation, and interview. While a learning process was on going from first to fifth week, observation on students' mathematics disposition was conducted. Written tests were used to measure mathematical power components including 3 (three) problems; mathematical communication (problem 1), mathematical reasoning (problem 2 and 4) and mathematical connection (problem 3). Questionnaires were compiled based on mathematical disposition components developed by James Beyers (Beyers, 2011). The questionnaire scoring system followed Likert scale. Questionnaire had obtained validation support from the expert team. The questionnaire data were collected from 30 students as respondents (samples).

\section{Instrument}

After completely compiled by the authors, and before used as a test, the instrument test was constructively validated by the expert team consisting of Prof. Dr. Sunandar (reviewer 1), Dr. Rasiman (reviewer 2), and Dr. Isnarto (reviewer 3 ). The reviewers conducted assessment with a scale of 1 to 5 . The assessment result were recorded on validation sheet represented in $\bar{x}$ score. The obtained average score $(\bar{x})$ shows the construction validity test of mathematical power ability implemented in learning. The results from the reviewers' assessment on mathematical power test items based on SOLO Taxonomy are as follows:

Based on the results from expert team's validation on test instruments, it was obtained that score for each validation aspect was more than 4.20 and the total average score was 4.37. The results from reviewers' assessment on test construction validity showed a very good category with a percentage of $87.4 \%$. Furthermore, it can be concluded that the test instrument is eligible for the research without any revisions.

Secondly, the instrument of written test consisting of 4 (four) items had been tested to 20 students. The results of the test instrument were recorded and analyzed for each item. The results of the test item validity used product moment correlation formula with 20 students as respondents with $5 \%$ significance level. The results can be seen in Table 3 as follows.

An item is said to be valid if it showed $r_{x y}>r_{\text {table }}$, and if $r_{x y} \leq r_{\text {table }}$ then the item was invalid. The Value of $r_{\text {table }}$ for $\mathrm{N}=20$ was $r_{\text {table }}=0.444$. Based on Table 3,100\% of the items are said to be valid, meaning that all four items are in line with the criteria and not diverged from the reality. All those four items have valid criteria so they could be used as the test instruments. The items could be instantly used or inserted to items file as archive. Calculation of reliability 
coefficient used Alpha formula with 5\% significance level. The result showed that the value of $r_{\text {table }}$ was 0.444 , and $r_{11}$ was 0.797 . The Interpretation of reliability coefficient $\left(r_{11}\right)$ was on interval $0.70 \leq r_{11} \leq 0.90$ meaning that the instruments has high reliability.

Table 2

The Resultsfrom Reviewers' Assessment on Questions' Construction

\begin{tabular}{lcccc} 
Validation Aspects & $\begin{array}{c}\mathbf{1}^{\text {st }} \mathbf{R} \\
\text { eviewer } \\
\text { score }\end{array}$ & $\begin{array}{c}\mathbf{2}^{\text {st }} \\
\text { Reviewer } \\
\text { score }\end{array}$ & $\begin{array}{c}\mathbf{3}^{\text {st }} \\
\text { Reviewer } \\
\text { score }\end{array}$ & $\begin{array}{c}\text { Average } \\
\text { Score }\end{array}$ \\
\hline Test Completion & 5 & 5 & 5 & 5.00 \\
Outline & 4 & 4 & 5 & 4.33 \\
Guidance & 4 & 5 & 4 & 4.33 \\
Items & 4 & 5 & 4 & 4.33 \\
Answer Sheets & 5 & 5 & 4 & 4.67 \\
Scoring Guidance & 4 & 4 & 5 & 4.33 \\
Relation between & 4 & 5 & 4 & 4.33 \\
mathematical power and & & & & \\
SOLO & 4.28 & 4.71 & 4.42 & 4.37 \\
\hline Total Average Score $\bar{x}$ & $85.6 \%$ & $94.2 \%$ & $88.4 \%$ & $87.4 \%$ \\
\hline Percentage & \multicolumn{4}{c}{} \\
\hline
\end{tabular}

Table 3

Validity of the test

\begin{tabular}{cccc}
\hline $\begin{array}{c}\text { Item } \\
\text { Numbers }\end{array}$ & $\begin{array}{c}\text { The Value of } \\
\mathbf{r}_{\mathbf{x y}}\end{array}$ & $\begin{array}{c}\text { The Value of } \mathbf{r}_{\text {table, }} \\
\text { Sig. 5\% }\end{array}$ & Decision \\
\hline 1 & 0.893 & 0.444 & Valid \\
2 & 0.733 & 0.444 & Valid \\
3 & 0.859 & 0.444 & Valid \\
4 & 0.511 & 0.444 & Valid \\
\hline
\end{tabular}

Questionnaires that have been validated by the validator team is then questionnaires tested to 20 students in grade 8 in different study groups. To determine the level of validity of items questionnaire (mathematical disposition) used in the study, then tested the validity of Product Moment Correlation Person. The data obtained were analyzed through SPSS version 20 with the results as shown in Table 4.

From the output in Table 4, all questionnaire items have $r_{x y}$ value more than $r_{\text {table }}$ value 0.444 at significance level 0.05 . Thus, all questionnaire items are said to be valid and the questionnaire can be used as a research instrument.Testing the level of questionnaire reliability (mathematical disposition) was done through Cronbach's Alpha reliability test with SPSS version 20. Data was taken from a questionnaire test of 20 students. Reliability test was done so that questionnaire can really be trusted as data collecting tool of research. From the data processing output obtained value of Cronbach's 
Alpha $=0.770>r_{\text {table }}=0.444$, it means the questionnaire items (mathematical disposition) are said to be reliable at a significant level of 0.05 . Thus, a questionnaire can be trusted as a good instrument in research.

Table 4

Validity of the Questionnaire

\begin{tabular}{cccccccc}
\hline $\begin{array}{c}\text { Item } \\
\text { Numbers }\end{array}$ & $\mathbf{r}_{\mathbf{x y}}$ & rtable & Decision & $\begin{array}{c}\text { Item } \\
\text { Numbers }\end{array}$ & $\mathbf{r}_{\mathbf{x y}}$ & rtable & Decision \\
\hline 1 & 0.561 & 0.444 & Valid & 11 & 0.500 & 0.444 & Valid \\
2 & 0.482 & 0.444 & Valid & 12 & 0.576 & 0.444 & Valid \\
3 & 0.576 & 0.444 & Valid & 13 & 0.500 & 0.444 & Valid \\
4 & 0.558 & 0.444 & Valid & 14 & 0.482 & 0.444 & Valid \\
5 & 0.467 & 0.444 & Valid & 15 & 0.561 & 0.444 & Valid \\
6 & 0.450 & 0.444 & Valid & 16 & 0.482 & 0.444 & Valid \\
7 & 0.582 & 0.444 & Valid & 17 & 0.612 & 0.444 & Valid \\
8 & 0.608 & 0.444 & Valid & 18 & 0.720 & 0.444 & Valid \\
9 & 0.608 & 0.444 & Valid & 19 & 0.608 & 0.444 & Valid \\
10 & 0.449 & 0.444 & Valid & 20 & 0.522 & 0.444 & Valid \\
\hline
\end{tabular}

Data coding and analysis

Quantitative data obtained in this study were processed and analyzed using SPSS version 11.5. Testing of statistical data carried out includes simple regression analysis. Result of the questionnaires was analyzed in order to categorize them into productive and negative mathematical disposition level. To support the result of this study, in-depth interviews conducted toward student representatives as selected subjects by using purposive snowball technique. Interview results were made in a transcript form and described through specific coding and analyzed carefully. The research data were examined its validity by using triangulation method (Creswell, 2014).

\section{Result}

Result of mathematical power ability test obtained from 30 students is presented in Table 5 below.

\section{Table 5}

\section{Statistics of Mathematical Power Test Scores}

\begin{tabular}{lr}
\hline N & 30 \\
Mean & 74.27 \\
Std. Error of Mean & 2.238 \\
Median & 75.00 \\
Mode & 83 \\
Std. Deviation & 12.259 \\
Variance & 150.271 \\
Range & 50 \\
Minimum & 48 \\
Maximum & 98 \\
Sum & 2228 \\
\hline
\end{tabular}


Based on the statistic, it was informed that result of mathematical power ability test obtained from 30 students is as follows: the minimum score was 48 , the maximum was 98, and the average score was 74.27. The achievement of mathematical power ability score was 74.27 and categorized as good. Then, the mathematical disposition questionnaires filled in by students was processed so that the result showed in the following Table 6 could be obtained.

\section{Table 6}

\section{Score Achievement of Mental Function of Mathematical Disposition}

\begin{tabular}{llc}
\hline Modes of Mental Functioning & $\begin{array}{l}\text { Subcategory of } \\
\text { dispositional } \\
\text { function }\end{array}$ & $\begin{array}{c}\text { Mathematical } \\
\text { Disposition } \\
\text { Productive Score }\end{array}$ \\
\hline Dispositional cognitive function & Connections & 65 \\
& Argumentation & 71 \\
\hline \multirow{3}{*}{ Dispositional affective function } & Nature of & 38 \\
& Mathematics & 75 \\
& Usefulness & 66 \\
& Worthwhileness & 75 \\
& Sensibleness & 70 \\
& Self-Concept & 67 \\
& Attitude & 72 \\
\hline Dispositional conative function & Math Anxiety & 69 \\
\hline Mean score & Effort/Persistence & 66.8 \\
\hline
\end{tabular}

Table 6 indicated of achievement by mathematical disposition indicators by which $66.8 \%$ of students had productive disposition on mathematics (mathematics learning). To determine the effect of mathematical disposition on mathematical forces, the data were analyzed with results as shown in Table 7 below.

Table 7

\section{Output Coefficients}

\begin{tabular}{cccccc}
\hline Model & \multicolumn{2}{c}{ Unstandardized Coefficients } & $\begin{array}{c}\text { Standardized } \\
\text { Coefficients }\end{array}$ & t & Sig. \\
\cline { 2 - 4 } & B & Std. Error & Beta & & \\
\hline (Constant) & 34.022 & 5.944 & & 5.724 & .000 \\
Var_MP_Y & .442 & .079 & .726 & 5.592 & .000 \\
\hline a. Dependent Variable: Var_Mathematical Disposition_X & &
\end{tabular}

Based on output coefficients table above, it was obtained that value of $a=$ 34.022 and $b=0.442$ so the regression equation $Y=34.022+0.442 X$, to accept or decline could be seen on Table 8 below. 
Table 8

\section{Regression Test}

\begin{tabular}{|c|c|c|c|c|c|}
\hline Model & Sum of Squares & df & $\begin{array}{c}\text { Mean } \\
\text { Square }\end{array}$ & $\mathbf{F}$ & Sig. \\
\hline 1 Regression & 2712.485 & 1 & 2712.485 & 28.608 & $.000^{\mathrm{b}}$ \\
\hline Residual & 2654.882 & 28 & 94.817 & & \\
\hline Total & 5367.367 & 29 & & & \\
\hline
\end{tabular}

a. Dependent Variable: MathPower_Y

b. Predictors: (Constant), Disposition_X

Considering the result of data analysis using SPSS version 20.0 was obtained Table 7 Regression Test, $0.000^{\mathrm{b}}$ less than 0.05 on the column of significance value ( $\mathrm{Sig})$, so that the null hypothesis $\left(\mathrm{H}_{0}\right)$ was rejected and the alternative hypothesis $\left(\mathrm{H}_{1}\right)$ was accepted. It used the interpretation that variable $X$ had linear relation to variable $Y$ with a fairly significant regression coefficient.

While the magnitude of influence of variable $\mathrm{X}$ to $\mathrm{Y}$, indicated by index discrimination $\mathrm{R}$ square equal to 0,528 or $52.8 \%$. The $\mathrm{R}$ square value showed that variety on mathematical power variable ability $(\mathrm{Y})$ could be explained by mathematical disposition variable $(\mathrm{X})$ by $52.8 \%$. In other words, variable $\mathrm{X}$ influenced variable $\mathrm{Y}$ by $52.8 \%$ at significance by regression model $\mathrm{Y}=$ $34.022+0.442 \mathrm{X}$ and by $47.2 \%$ of another variable except those influencing variable $Y$.

\section{Dispositional Cognitive Function Subcategory}

The subcategory of dispositional cognitive function was a mathematical connection belonged to a subcategory of cognitive dispositional function defined as a tendency to make connections within or across mathematical topics. Guided by Figure 1, there are $65 \%$ of students who could show a tendency to have a broad knowledge of several topics in mathematics and able to make interrelationships between topics in mathematics, but $35 \%$ of students had no a tendency to make relationships between topics or ideas in mathematics. Consider the following interview conversation.

Teacher : Can the area of triangle $\mathrm{ABC}$, with just base and side size, be counted?

Student (1) : Yes, it can.

Teacher : How do you get an idea to solve the area of right angle triangle?

Student (1) : First, find the height of the triangle using Pythagorean formula.

Teacher : And then?

Student (1) : Secondly, after the height of triangle ABC is found, put it into the formula of triangle area. Surely the area will be obtained.

Understanding the conversation between teacher and student, it can be described that, in the context of problem solving, students had the ability to 
make inter-idea connections in mathematics. This statement was in accordance with previous research that mathematical knowledge can be derived from making mathematical connections (Hoyles \& $\mathrm{Ku}, 2006$ ), for the connection could serve as a basis for the development of new mathematical knowledge.

Arguments (excuses) include in subcategories of dispositional cognitive functions defined as the tendency to evaluate the truth of mathematical reports, to make mathematical arguments, and to justify mathematical statements, etc. There were $71 \%$ of students having a productive disposition and $29 \%$ having a negative disposition. This was an intelligent process by which students could see mathematical explanations that generated new knowledge.

Teacher : Why should Pythagoras rules? Anything else?

Student (1) : In right triangle $A B C$, equation $c^{2}=a^{2}+b^{2}$ works.

If (at least) two sides' length are known, so the other side length can be determined.

Teacher : Good idea.

The previous conversation indicated that students had good reasons as reasonable arguments to evaluate mathematics tasks.

\section{Subcategory Dispositional Affective Function}

Beliefs about mathematics are procedural or conceptual. Subcategories of the dispositional function on mathematics nature are defined as tendency to believe that mathematics consists of interrelated concepts. As many as $38 \%$ of students had a belief on about mathematics nature as a connected and constructible concept system (Kloosterman, 2002). Meanwhile, the $62 \%$ of students had a perception on mathematics as a system of unconnected facts and procedures. These results showed a more dominant negative mathematical disposition by most of students. Consequently, it affected the problem-solving process that are not complete. Students only considered mathematics as a partial concept, so that when they were stuck out, they would be difficult to connect with other mathematical knowledge.

Subcategory of usefulness dispositional function is defined as a tendency to believe or a belief on mathematics usefulness to meet current or future needs (inside or outside school) such as for students' career, etc. Consider the following interview results.

Teacher : Do you think that learning mathematics is useful for you?

Student (2) : Absolutely, it is useful to maintain learning achievement and solve daily problems.

Teacher : Would you please mention a real example?

Student (2) : Learning mathematics is useful to estimate the budget for painting my house

Teacher : What do you want for your future career?

Student (2) : I am going to take architecture 
The previous interview conversation represented $75 \%$ of students who believed that learning mathematics is useful for solving current or future problems (inside and outside school) for their careers. While $25 \%$ of other students did not know the usefulness of mathematics in the future. Understanding the importance of mathematics as a future career will encourage students to prepare their learning since earlier. This result was in accordance with an educational research literature saying that children need to be better prepared in STEM area since elementary years, in order to prepare their future career(Madden, Beyers, and Brien, 2016).

Subcategory of worthwhileness dispositional functions could be considered as a tendency to believe that works had been done by students to study mathematics was worthy and valuable for them. About $66 \%$ of students stated that the assessment on their mathematics tasks was worthy and valuable to them. Meanwhile, $34 \%$ of students did not believe in it.

Subcategory of sensibleness dispositional function is considered as a tendency to believe that mathematics consists of interpretable ideas or concept. According to Carvalho and Pedro, through mental representations, we give meaning to phenomena and explain concepts and mathematical ideas (Carvalho and Pedro, 2017). About $75 \%$ of students had a productive disposition to this sensibleness. Students successfully completed complex mathematical tasks. Students could understand abstract ideas or concepts very well. However, 25\% of students in this case had unproductive dispositions.

A person's self-concept on mathematics is a belief about self and that persistence leads to a successful learning. As National Council of Teachers of Mathematics stated that disposition refers not only to attitudes but a tendency to think and act in a positive way (NCTM, 2014).The tendency to monitor and reflect on thinking process and self-performance. Included in this self-concept is the thinking tendency to his own self, relating to a student's awareness on his ability to develop various ways that may be pursued in solving problems (Lukum, Laliyo, and Sukamto, 2010; Panjaitan, 2015). About 70\% of students thought about how he was able or unable to complete the task and always reflected on task achievement result. The remaining 30\% of students did not think about how he was able or unable to finish it. Consider the interview below.

Teacher : Before doing the task, do you think that you are able to solve the problems?

Student (2) : I always think that I will be able to finish the task

Teacher : Did you reflect on task achievement result?

Student (2) : Yes, I did.

Teacher : How did you do the reflection?

Student (2) : I corrected the wrong answers on the previous mathematics task.

This self-concept is better known as metacognition, that is, the process of realizing and managing students' way of thinking (Lukum, Laliyo, and Sukamto, 2015; Panjaitan, 2015). A high level of awareness to realize and manage this way of thinking will lead to successful mathematics learning. 
Emotional reaction of respondents to mathematical activity inside or outside school are related to the attitude or reaction of students (respondents) to a certain emotional such as like or dislike to mathematics learning activities inside and outside of school. About $67 \%$ of students preferred mathematical activities (by applying a group investigation learning model) because mathematical activities were very challenging and fun for them. Meanwhile, about $33 \%$ of students did not like mathematical activities because mathematics had many complicated formulas or theories. Students with negative mathematical dispositions generally performed their dislike in mathematics learning activities (An, Zhang, Flores, Chapman, Tillman, \& Serna, 2015).

In this research, the obtained data proved that students with positive disposition or had a favor to mathematics had an average score of 79 in mathematical power tests and those with negative disposition or disliked mathematics had only 53 average score in mathematical power test. This change could be done by increasing the affective domain of students in learning mathematics. Not only students' cognitive abilities, affective factors also had a major effect on student problem solving abilities (Blanco, Guerrero, Ann, Carrasco, \& Ana, 2013).

Students got anxious or not in relation to mathematics. Some students in the upper group (high cognitive ability) had higher anxiety than those in the lower group (low cognitive abilities) in dealing with mathematics tasks. Notice the interview below.

$\begin{array}{ll}\begin{array}{l}\text { Teacher } \\ \text { Student (3) }\end{array} & : \text { Do you feel anxious when you have a mathematics test? } \\ \text { Teacher } & : \text { Why do you get anxious? You are a smart student } \\ & \text { though. } \\ \text { Student (3) } & : \begin{array}{l}\text { I am afraid I will not be able to do the test well. I am } \\ \text { afraid of the result then too. }\end{array} \\ \text { Teacher } & : \text { What did you prepare for the test? } \\ \text { Student (3) } & : \text { I studied hard and practiced a lot. }\end{array}$

Students in the upper group were generally very anxious when they had mathematics exams. They were anxious and afraid the result of the exam. However, effects of the anxiety itself was a positive impact for the way students learned. They would prepare for the exam more carefully. On the other hand, low group students did not care about the result. They still considered the test result as not significantly affecting overall learning achievement. This finding is in line with Ramirez, et al., saying that children at higher levels may be most susceptible to adverse effects of mathematical anxiety and are particularly worrying because these students can be said to have a greatest potential for high achievement in mathematics (Ramirez, Gunderson, Levine, \& Beilock, 2013).

In general, according to Adam Feldhaus (Feldhaus, 2014), dispositional affective function as an affective element of mathematical disposition influences the way students make decisions to learn mathematics. This statement is in line with the result of National Council of Teachers of Mathematics 
research (1989) arguing that mathematical disposition is not only an attitude but a tendency to think and act in a positive way.

\section{Subcategory of conative dispositional function}

Purpose of subcategory of persistence dispositional function is a tendency to assess how much students feel that hard work and persistence are important when they involve in mathematical activities. About $69 \%$ of students were always trying hard to complete the mathematics tasks by trying to find other learning sources. On the other hand, about $31 \%$ of students were easily desperate when they faced difficult mathematics tasks. Consider the interview below.

$\begin{array}{ll}\text { Teacher } & : \begin{array}{l}\text { What kind of efforts did you do to complete } \\ \text { mathematical problem solving activities? }\end{array} \\ \text { Student (1) } & : \text { I studied every day and read a lot of books. } \\ \text { Student (2) } & : \begin{array}{l}\text { I had some discussions with friends and asked to the } \\ \text { teacher. }\end{array} \\ \text { Teacher } & : \begin{array}{l}\text { What kind of effort will you do if you fail the } \\ \text { mathematics test? }\end{array} \\ \text { Student (3) } & : \text { I will still study even after the test. } \\ \text { Teacher } & : \text { Do you feel that you did enough efforts to improve your } \\ & \text { achievement? }\end{array}$

Student (3) : No, it was not enough, I will keep studying on that.

Based on the previous interview, students had a hard effort, persistent and not easily give up in completing mathematics tasks. This is in line with the results of previous research saying that student's hard and persistent efforts in studying is the most influential mathematical disposition component toward problem solving, so that teachers can integrate it into activities that can improve students' problem solving abilities (Rahayu and Kartono, 2014).

\section{Discussion}

Result of analysis on quantitative data from mathematical power ability test indicated that the achievement of average score in mathematical power ability test was 74.27 as in good category. The average score had exceeded the target of minimum passing grade by 70.0. Result of questionnaire indicated that $66.8 \%$ of students had productive disposition tendency on mathematics. The questionnaire data showed that students still had a fairly high tendency to be interested in mathematics to support their learning success.

In detail, the attainment of each dispositional subcategory indicator was shown in Table2, informing that the average score for dispositional cognitive function subcategory was $68 \%$ for productive disposition. This information indicated that students' disposition toward mathematics on cognitive mental function was in a fairly high level. On the subcategories of dispositional affective function, the average score of productive disposition was $66 \%$, meaning that student's disposition to mathematics on cognitive mental function was in fairly high level. Although, if there is a subcategory of dispositional 
affective function with a disposition score of only $38 \%$ (nature of mathematics), it can be explained that students do not always have the same disposition in each subcategory of dispositional mental functions. Thus, an individual may have a productive mathematical disposition in one area but is unproductive in another area (Feldhaus, 2014). In subcategories of dispositional conative function, $69 \%$ of productive disposition score and nonproductive disposition of $31 \%$, explains that students' disposition to mathematics on cognitive mental function at the high level.

Attempts to change from a nonproductive to a productive disposition to mathematics is not an easy task. As revealed by Adam Feldhaus, mathematical dispositions were formed in students' mathematics career, and very difficult to change them in the future (Feldhaus, 2012; 2014). However, Philippou and Christou revealed that, after students' attitudes and beliefs about mathematics were developed, they had a fairly encouraging level of stability and intensity (Philippou \& Christou, 2002). Next, it will be discussed about the attainment of each subcategory indicator of dispositional mental functions based on the results of teacher interviews to students as follows.

Based on the results of inter analyzing interview data the following shows the attainment of each subcategory indicator of dispositional mental functions as follows. At the end of this discussion, in general, the achievement of mathematical disposition indicator on the three dispositional mental functions reached $66.8 \%$ with 'fairly high' disposition category. The average score of the mathematics ability test reached 74.27. The correlation between mathematical disposition and mathematical power was shown by the contribution of the influence of mathematical disposition $(\mathrm{X})$ on the ability of mathematical power (Y) in mathematical learning through group investigation model. In other words, students' ability to use mathematical knowledge as a mathematical power in problem solving supported the existence of dispositional mental functions and mathematical ability to become self-confidence of the emergence of mathematical dispositions. It was clear (see Table 2) in the dispositional cognitive function where subcategories of connection and argumentation became part of the developed mathematical disposition. It was in line with Pilten's (2010) saying that connection and argumentation (reasoning and giving reasons) abilities are two of the three essential components of mathematical power (Pilten, 2010).

\section{Conclusion}

Result of quantitative research showed that (1) the average score in mathematical power ability test was 74.27 in good category, (2) the mean score for productive mathematical disposition was 66.8 and for unproductive mathematical disposition was 33.2, (3) there was influence of mathematical disposition $(\mathrm{X})$ by $52.8 \%$ on mathematical power $(\mathrm{Y})$ by linear regression equation $\mathrm{Y}=34.022+0.442 \mathrm{X}$ with significance level by $0.95(\alpha=0.05)$. (4) 
The achievement of average score for productive mathematical disposition (positive disposition) was $66.8 \%$. The indicator achievement in dispositional cognitive function subcategory was $66 \%$, while in dispositional affective function subcategory was $65 \%$, and in dispositional conative function subcategory was $66 \%$. The average score of mathematics disposition reached $66.8 \%$, so that those three had 'fairly high' category. (5) Result of qualitative research showed the existence of internal consistency between the three mental functions of mathematical disposition. Mutual relations also occurred between mathematical power and mathematical disposition. Students' ability to use mathematical knowledge as a mathematical power in non-routine problem solving through mathematical connections, logical reasoning or argumentation, and mathematical communication was to develop self-confidence and productive mathematical dispositions. Meanwhile, productive mathematical disposition would build a tendency to improve students' mathematical power. Mathematical disposition is an important integral factor to influence the way students engage in mathematical activities. Teachers' next role is to monitor students' mathematical disposition to remain a productive mathematical disposition. If there is a symptom of decreased maternal disposition, the teacher immediately acts by doing a review of the learning done in the school. Considering different conditions, researchers interested in mathematical power development can still observe from other variables' point of view.

\section{Acknowledgments}

Thanks to many who have supported this research are promoters, validators, dissertation reviewers and leaders of the Sultan Agung Islamic University of Semarang Indonesia which has provided funds for the implementation of this research.

\section{Reference}

An, S. A., Zhang, M., Flores, M., Chapman, J. R., Tillman, D. A., \& Serna, L. (2015). Music Activities as an Impetus for Hispanic Elementary Students' Mathematical Disposition. Journal of Mathematics Education, $8(2), 39-55$. Retrieved from http://educationforatoz.com/images/2015_Song_An.pdf

Beyers, J. (2011). Development and evaluation of an instrument to assess prospective teachers ' dispositions with respect to mathematics. International Journal of Business and Social Science, 2(16), 20-33.

Blanco, L. J., Guerrero, E., Ann, B., Carrasco, C., \& Ana, B. (2013). The Mathematics Enthusiast Cognition and Affect in Mathematics Problem Solving with Prospective Teachers Cognition and Affect in Mathematics Problem Solving with Prospective Teachers 1. The Mathematics Enthusiast, 10(10), 334-364. Retrieved from http://scholarworks.umt.edu/tme 
BSNP. Salinan Permendikbud R.I. Nomor 64 Tahun 2013.Tentang Standar Isi Pendidikan Dasar dan Menengah., Pub. L. No. 1-114, 1 (2013).

Kemendikbud RI. Retrieved from https://luk.staff.ugm.ac.id/atur/bsnp/Permendikbud64-2013StandarIsi.pdf

Carvalho and Pedro. (2017). Mental Computation with Rational Numbers : S tudents ' Mental Representations. Journal of Mathematics Education, 10(2), 17-29.

Christopher T. Cross, Taniesha A. Woods, and H. S. (2009). Mathematics Learning in Early Childhood: Paths Toward Excellence and Equity. (Committee on Early Childhood Mathematics; National Research Council, Ed.). The National Academic Press, Washinton, D.C. Retrieved from https://www.researchgate.net/file.PostFileLoader.html?id...assetKey...

Creswell, J. W. (2014). Research Design: Qualitative, Quantitative, and Mixed Methods Approaches. SAGE Publications, Inc. 2455 Teller Road Thousand Oaks, California 91320.

Diezmann, C. M., Watters, J. J., \& English, L. D. (2001). Implementing mathematical investigations with young children. Proceedings 24 th Annual Conference of the Mathematics Education Research Group of Australasia, 170-177,.

Feldhaus, C. A. (2014). How Pre Service Elementary School Teachers' Mathematical Dispositions are Influenced by School Mathematics. American International Journal of Contemporary Research, 4(6), 91-97. Retrieved from http://www.aijcrnet.com/journals/Vol_4_No_6_June_2014/11.pdf

Herna, Nusantara, T., Subanji, \& Mulyati, S. (2016). The Characterization Of True Pseudo Construction In Understanding Concept Of Limit Function. IOSR Journal of Research \& Method in Education, 6(5), 77-87. https://doi.org/10.9790/7388-0605037787

Hoyles, C., \& Ku, D. (2006). and Patterns in Its Development : Insights, 581608. Retrieved from file://C:/Users/user/AppData/Local/Mendeley Ltd./Mendeley Desktop/Downloaded/Hoyles, Ku - 2006 - AND PATTERNS IN ITS DEVELOPMENT INSIGHTS.pdf

Kloosterman, P. (2002). Beliefs About Mathematics and Mathematics Learning in the Secondary School: Measurement and Implications for Motivation. In Beliefs: A Hidden Variable in Mathematics Education? (pp. 247-269). Dordrecht: Kluwer Academic Publishers. https://doi.org/10.1007/0-306-47958-3_15

Kusmaryono, I., \& Suyitno, H. (2015). Mathematical Power's Description of Students in Grade 4 th Based on The Theory of Constructivism. International Journal of Education and Research, 3(2), 299-310. Retrieved from http://www.ijern.com/journal/2015/February-2015/25.pdf Lukum, A., Laliyo, L. A. R., \& Sukamto, K. (2015). Metakognisi Mahasiswa Dalam Pembelajaran Kesetimbangan Kimia. Jurnal Ilmu Pendidikan, 
21(1), 9-18.

Madden, L., Beyers, J., \& Brien, S. O. (2016). The Importance of STEM Education in the Elementary Grades: Learning from Pre-service and Novice Teacher Perspectives, 20(5), 1-18.

Mueller, M., \& Hindin, A. (2011). An analysis of the tactors that influence preservice elementary teachers' developing dispositions about teaching all ahildren. Issues in Teacher Education, 20(1), 17-34. https://doi.org/10.1080/08878730.2010.489992

National Council of Teachers of Mathematics. (2000). Principles and Standards - National Council of Teachers of Mathematics. Retrieved December 21, 2017, from http://www.nctm.org/Standards-andPositions/Principles-and-Standards/

NCTM. (1989a). A Vision of Mathematical Power and Appreciation for All. Chapter 1. Retrieved from www.sde.ct.gov/sde/lib/sde/PDF/.../mathgd_chpt1.pdf

NCTM. (1989b). NCTM Evaluation Standard 10: Mathematical Disposition. Retrieved December 15, 2017, from http://webapp1.dlib.indiana.edu/virtual_disk_library/index.cgi/4273355/F ID3542/DOCS/ENC2280/28023310.HTM

NCTM. (2014). NCTM Disposition $2011 \mid$ mjcoonkitt. Retrieved December 15, 2017, from https://mjcoonkitt.wordpress.com/2014/06/18/nctmdisposition-2011/

Panjaitan, B. (2015). Karakteristik Metakognisi Siswa. Jurnal Ilmu Pendidikan, 21(1), 19-28.

Philippou, G., \& Christou, C. (2002). A Study of the Mathematics Teaching Efficacy Beliefs of Primary Teachers. In Beliefs: A Hidden Variable in Mathematics Education? (pp. 211-231). Dordrecht: Kluwer Academic Publishers. https://doi.org/10.1007/0-306-47958-3_13

Phillips, E., \& Anderson, A. (1993). Developing mathematical power: A case study. Early Child Development and Care, 96(1), 135-146. https://doi.org/10.1080/0300443930960111

Pilten, P. (2010). Evaluation of mathematical powers of 5th grade primary school students. Procedia - Social and Behavioral Sciences, 2(2), 29752979. https://doi.org/10.1016/j.sbspro.2010.03.450

Rahayu, R., \& Kartono. (2014). The Effect of Mathematical Disposition toward Problem Solving Ability Based On IDEAL Problem Solver. International Journal of Science and Research (IJSR), 3(10), 2012-2015.

Ramirez, G., Gunderson, E. A., Levine, S. C., \& Beilock, S. L. (2013). Math Anxiety, Working Memory, and Math Achievement in Early Elementary School. Journal of Cognition and Development, 14(2), 187-202. https://doi.org/10.1080/15248372.2012.664593

Şahin, S. M., \& Baki, A. (2010). A new model to assess Mathematical Power. Procedia - Social and Behavioral Sciences, 9, 1368-1372. https://doi.org/10.1016/j.sbspro.2010.12.336 
Scusa, T. (2008). Five Processes of Mathematical Thinking. Summative Projects for MA Degree, 1-92. Retrieved from http://digitalcommons.unl.edu/cgi/viewcontent.cgi?article=1030\&context $=$ mathmidsummative

Subanji, \& Nusantara, T. (2016). Thinking Process of Pseudo Construction in Mathematics Concepts. International Education Studies Journal, 9(2), 16-32. https://doi.org/10.5539/ies.v9n2p17

Yeşildere, S., \& Türnüklü, E. (2008). An investigation of the components affecting knowledge construction processes of students with differing mathematical power. Egitim Arastirmalari - Eurasian Journal of Educational Research, (31), 151-169.

\section{Authors:}

Imam Kusmaryono, M.Pd

Sultan Agung Islamic University

E-mail: kusmaryono@unissula.ac.id

Dr. Dwijanto, $M S$

Semarang State University

Central Java, Indonesia
Prof. Dr. Hardi Suyitno

Semarang State University

Central Java, Indonesia

Dr. Nur Karomah Dwidayati

Semarang State University

Central Java, Indonesia 
Appendix A:

Table 9. Outline of essay (written) test items

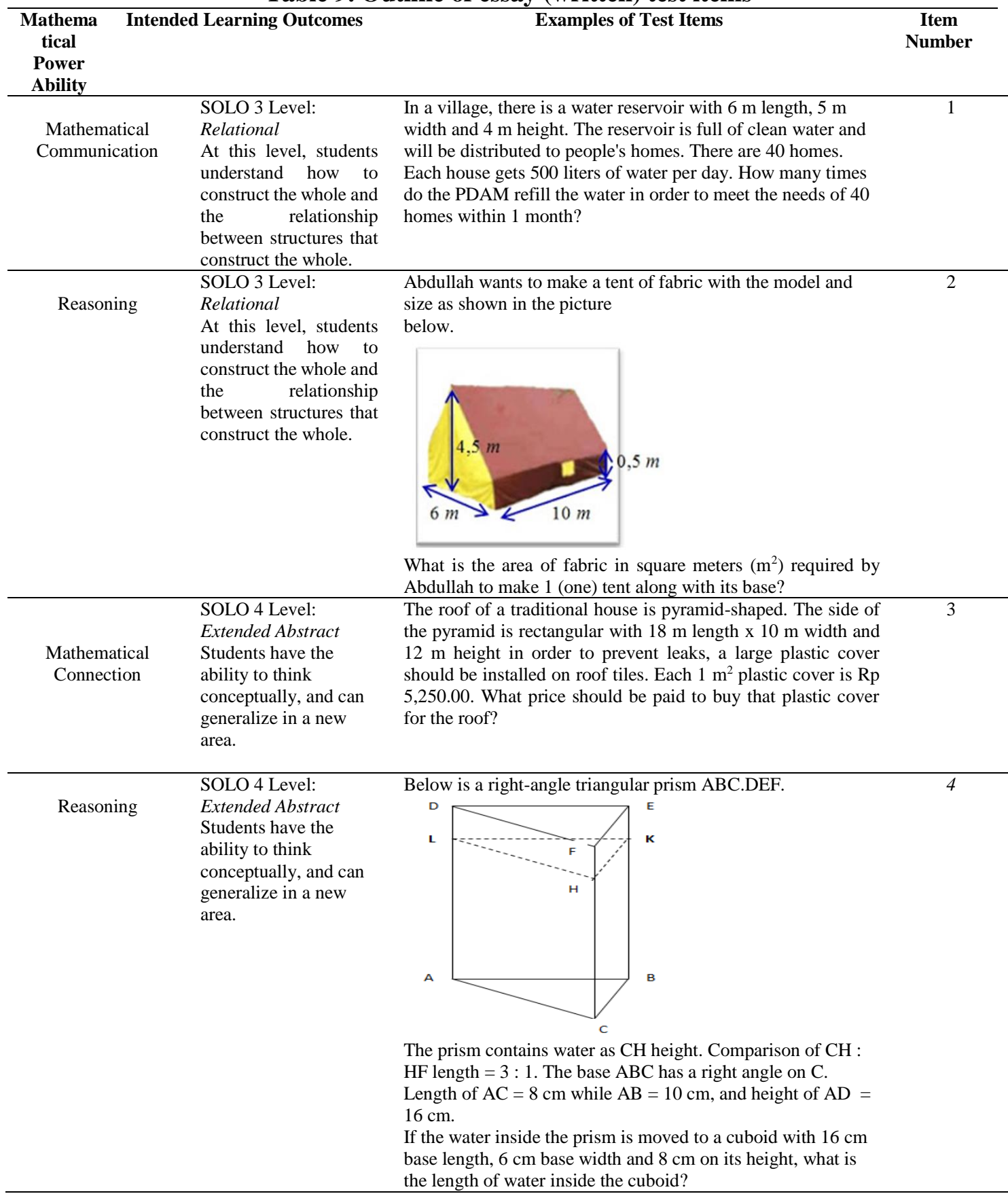

Appendix B: 
Table 10. Outline of Questionnaire for Mathematical Disposition

\begin{tabular}{|c|c|c|c|}
\hline $\begin{array}{l}\text { Modes of } \\
\text { Mental } \\
\text { Functioning }\end{array}$ & $\begin{array}{l}\text { Subcategory of } \\
\text { dispositional } \\
\text { function }\end{array}$ & Statement of Questionnaire & $\begin{array}{l}\text { Item } \\
\text { Number }\end{array}$ \\
\hline $\begin{array}{l}\text { Dispositional } \\
\text { cognitive }\end{array}$ & Connections & $\begin{array}{l}\text { I believe that, in mathematics, there is a relationship } \\
\text { between topics or lessons each other. }\end{array}$ & 1 \\
\hline \multirow[t]{3}{*}{ function } & & $\begin{array}{l}\text { I am not able to relate ideas or topics in and across } \\
\text { mathematics. }\end{array}$ & 11 \\
\hline & Argumentation & $\begin{array}{l}\text { I believe that, by correcting or re-examining my work, the } \\
\text { result will be more satisfying. }\end{array}$ & 2 \\
\hline & & I can give a good reason for the result of my task. & 12 \\
\hline \multirow{13}{*}{$\begin{array}{l}\text { Dispositional } \\
\text { affective } \\
\text { function }\end{array}$} & $\begin{array}{l}\text { Nature of } \\
\text { Mathematics }\end{array}$ & $\begin{array}{l}\text { I do not believe that mathematics consists of systematic } \\
\text { concepts or rules or procedures. }\end{array}$ & 3 \\
\hline & & $\begin{array}{l}\text { I am currently solving mathematical problems based on } \\
\text { mathematics concepts or procedures. }\end{array}$ & 13 \\
\hline & Usefulness & $\begin{array}{l}\text { I am convinced that the mathematics I learned is useful for } \\
\text { improving school achievement and succeeding future } \\
\text { goals. }\end{array}$ & 4 \\
\hline & & I use mathematics knowledge in everyday problem solving. & 14 \\
\hline & Worthwhileness & $\begin{array}{l}\text { I believe that my mathematics task assessment result is } \\
\text { appropriate and qualified for me. }\end{array}$ & 5 \\
\hline & & $\begin{array}{l}\text { I consider my mathematics achievement to be a valuable } \\
\text { experience. }\end{array}$ & 15 \\
\hline & Sensibleness & $\begin{array}{l}\text { I believe that mathematics consists of ideas that can be } \\
\text { interpreted. }\end{array}$ & 6 \\
\hline & & $\begin{array}{l}\text { I communicate mathematical ideas through symbols, tables, } \\
\text { graphs, or diagrams to explain mathematical problems. }\end{array}$ & 18 \\
\hline & Mathematics & I feel confident that I can develop various ways to solve & 7 \\
\hline & oncept & $\begin{array}{l}\text { mathematics problems. } \\
\text { I do not care if I do not understand or not good at } \\
\text { mathematics. }\end{array}$ & 20 \\
\hline & Attitude & I consider that mathematics lessons are not fun to learn. & 8 \\
\hline & Math Anxiety & $\begin{array}{l}\text { I feel that mathematics does not fulfil my needs. } \\
\text { I feel anxious when I will have a test or mathematics exam. }\end{array}$ & 16 \\
\hline & & $\begin{array}{l}\text { I am shy (low self-confidence) if my mathematics score is } \\
\text { not good. }\end{array}$ & 19 \\
\hline $\begin{array}{l}\text { Dispositional } \\
\text { conative }\end{array}$ & Effort/Persistence & $\begin{array}{l}\text { When I get to have a difficult mathematical problem, I feel } \\
\text { challenged to work hard to find a solution. }\end{array}$ & 10 \\
\hline function & & $\begin{array}{l}\text { I seek for and read lessons from other sources to extend my } \\
\text { knowledge and understanding on mathematics. }\end{array}$ & 17 \\
\hline
\end{tabular}

